\title{
THE INFLUENCE OF ENTREPRENEURIAL INTENSITY AND CAPABILITIES ON INTERNATIONALISATION AND FIRM PERFORMANCE
}

\author{
Boris Urban and Mpho R Sefalafala
}

Wits Business School

Accepted: January 2015

\begin{abstract}
International entrepreneurship represents the process of discovering and creatively exploiting opportunities that exist outside a firm's national borders in order to obtain a competitive advantage. Firms in emerging economies are increasingly looking towards internationalisation since they are faced with rising competition in their domestic markets and attracted to opportunities in foreign markets. This article investigates international entrepreneurship by examining how the influence of entrepreneurial intensity and capabilities at the firm level influence performance, while at the same time considering environmental influences on this relationship. Based on past theoretical and empirical findings, hypotheses are formulated and then tested using correlational and regression analysis. Generally, the results support the hypotheses where both entrepreneurial intensity and capabilities are positively related to internationalisation and firm performance, while weak evidence is found for environmental hostility as a moderating influence. Several recommendations are made in light of the findings, where it is suggested that firms foster higher levels of innovativeness, risk-taking and proactiveness while developing human, social and technology related capabilities in order to enhance their performance and increase their levels of internationalisation.
\end{abstract}

Key words: international entrepreneurship, entrepreneurial intensity, capabilities, firm performance, exporting, South Africa

JEL: D8, J24, L26, M13

\section{$1 \quad$ Introduction}

The past decade has witnessed a rapid growth of internationalisation in firms from emerging markets (Chang, 2012; Liu, Li \& Xue, 2011). The rapid globalisation of world markets has encouraged firms of all sizes and national origins to expand internationally. Faced with rising competition in their domestic markets and attracted to opportunities in foreign markets, firms in emerging economies are increasingly looking towards internationalisation as a means of creating and sustaining a competitive advantage (Yiu, Lau \& Bruton, 2007).

International business practices and scholarly research have steadily acknowledged that other forms of international venturing exist outside the monolithic multinational enterprise (Buckley \& Casson, 2009; Goldstein, 2007; Oviatt \& McDougall, 2005a). Instead, researchers have used terms such as global start-ups, born-globals and international entrepreneurship, where in general these businesses seek to derive significant competitive advantage from their use of resources and through the scale of their outputs in multiple countries (Gammeltoft, Pradhan \& Goldstein, 2010; Ge \& Deng, 2011; Hoskisson, Eden, Lau \& Wright, 2000).

The focus of this article is on international entrepreneurship which represents the process of discovering and creatively exploiting opportunities that exist outside a firm's national borders in order to obtain a competitive advantage (Zahra \& George, 2002). Two steams of literature provide the theoretical foundations of this article, entrepreneurship and internationalisation. The importance of analysing internationalisation from an entrepreneurship perspective has been recognised, where international entrepreneurship necessitates a combination of innovative, proactive, and risk-seeking behaviour that crosses national borders and is intended to create value in firms (Oviatt \& McDougall, 2005b; Ripollés-Meliá Menguzzato-Boulard \& Sánchez-Peinado, 
2007; Shree \& Urban, 2012). More specifically, entrepreneurial behaviour at the firm-level has been studied with the entrepreneurial intensity (EI) construct (Kuratko, Morris \& Covin, 2011; Scheepers, Hough \& Bloom, 2007), which has been successfully used to empirically assess the level and frequency of entrepreneurship among firms in diverse industries.

In emerging economies such as South Africa, one of the primary goals of a firm is growth and this can be achieved by continuously innovating in the face of growing global challenges (Urban, 2010). Past research highlights the importance of export activity as an attractive mode of international entrepreneurship, where this type of venturing is viewed as an entrepreneurial act, consisting of identifying and exploiting new business opportunities in a new environment (Ripollés-Meliá et al., 2007). Such a foray into international markets is important for the growth and development of firms in emerging economies (Manolova, Manev \& Gyoshev, 2010; Urban, 2012) particularly as many firms are increasingly relying on exports for venturing into foreign markets (Cuyvers, Dumont, Viviers, De Pelsmaker, Muller, Jegers \& Saayman, 2008; Singh, 2009).

However the problem for many of these firms in emerging economies is that foreign opportunities are tempered by the constraints imposed by the competitive forces that exist in international environments, such as aggressive government intervention, technological changes, and fierce local rivalries (Jones, Coviello \& Tang, 2011). To overcome such environmental influences and obstacles, a broad range of capabilities are required for successful international expansion, where human, social and technological-based capabilities have been identified as crucial for venturing and internationalisation (Casillas Moreno, Acedo, Gallego \& Ramos, 2009; Shree \& Urban, 2012). Despite the importance of these capabilities to internationalisation, many firms in emerging markets face a shortage of skilled workers with international knowledge and managerial know-how to overcome barriers towards internationalisation. Moreover, a lack of human and technology-based capabilities means that these firms may not be able to acquire sufficient depth of technology learning to globalise their operations. Additionally, if a firm possesses few social and business networks or contacts, there may be lost opportunities in terms of the internationalisation process (Shree \& Urban, 2012).

Recognising these problems, this study responds directly to research calls to delve deeper into understanding international entrepreneurship by examining the influence EI and capabilities in terms of internationalisation and firm performance (Hansen. Deitz, Tokman, Marino \& Weaver, 2011; Kuratko et al., 2011). While prior research has established that entrepreneurial behaviour and unique entrepreneurial capabilities (EC) enable firms to make a leap into the international arena (Manolova et al., 2010), it is not yet fully understood how EI leads to successful internationalisation and/or increased firm performance. Moreover, much of the empirical work in international entrepreneurship is based primarily on firms in advanced economies (Singh, 2009), with few studies conducted in the context of emerging economies (Bruton, Ahstrom \& Obloj, 2008).

The study takes place in South Africa which remains a highly significant regional political and economic player in sub-Saharan Africa (SSA), and is member of the BRIC (Brazil, Russia, India, and China) cooperation mechanism, indicating its emergent international influence (Carmody, 2012). It is anticipated that this study will contribute to the international entrepreneurship literature by explaining the relationship between EI, entrepreneurial capabilities, and internationalisation and performance, while at the same time considering the moderating effect of environmental influences on this relationship.

The article starts by highlighting relevant theoretical foundations and unpacks the study variables to provide a basis on which the hypotheses are formulated. Next the research methodology is explicated and the hypotheses are tested using correlational and regression analysis. Results and implications follow. The article ends by highlighting study limitations and avenues for future research. 


\section{Brief theoretical overview}

\subsection{Internationalisation and entrepreneurship}

Several theoretical perspectives inform the internationalisation process of firms. The major perspectives are the network approach, the resource-based theory of internationalisation, and the organisational learning theory (see for instance: Shree and Urban (2012) for a consolidation of these different perspectives). Internationalisation is beneficial to accessing new markets, reducing the risk involved through diversification in different countries, engaging in a larger customer base and establishing an international network of suppliers that improve products and services for domestic customers (Buckley \& Casson, 2009).

Earlier research has noted that as industry internationalisation increases, the pressure on all firms in the industry to internationalise increases as well, which, in turn directly relates to firms venturing outside its country's borders (Jones et al., 2011). Oviatt and McDougall (2005b) illustrate that the importance of internationalisation is growing, and in order for firms to be profitable they must attain value-creating resources and capabilities. Recognising that opportunities through which a firm can expand are likely to be found in the global market rather than in its domestic environment (Goldstein, 2007), firms from emerging markets tend to develop a position that is innovative, visionary, and proactive to pursue such opportunities and respond rapidly when they do arise (Yamakawa, Peng \& Deeds, 2008). International entrepreneurship has been conceptualised as the process of discovering and creatively exploiting opportunities that exist outside a firm's national borders in order to obtain competitive advantage (Oviatt \& McDougall, 2005a; Zahra, Cloninger, Yu \& Choi, 2004). The business environment in many emerging economies, such as in China has become more conducive to entrepreneurial activity where many new firms are now strategically repositioning themselves for internationalisation (Yang Jiang, Kang \& Ke, 2009). Song, Wang and Parry (2010) consider entrepreneurship as a key driver of economic development, where a firm's entrepreneurial orientation plays an important role.

International entrepreneurship has been positioned at the nexus of internationalisation and entrepreneurship where entrepreneurial behaviour involves cross-border business activity (Zahra \& George, 2002). Research in internationalisation has advanced to incorporate empirical developments in entrepreneurship research (Jones et al., 2011), where particular interest has been paid to examining entrepreneurship (at a firm level) as a process of behaviour manifesting in entrepreneurial events, and exhibiting entrepreneurial orientations (Javalgi \& Todd, 2010).

Entrepreneurial orientation incorporates firm-level processes, practices and decision-making styles where entrepreneurial behavioural patterns are recurring (Covin, Green \& Slevin, 2006). The theoretical basis of the entrepreneurial orientation construct lies in the assumption that all firms have an entrepreneurial orientation even if the levels are very low (Lyon, Lumpkin \& Dess, 2000). Having an entrepreneurial orientation is one of the prerequisites for firm success, where researchers point out that any firm with high levels of entrepreneurial orientation tends to be innovative and encourages creative initiatives in new products and service development, particularly in the space of new technologies and novel ideas (Lyon et al., 2000; Van Vuuren \& Wörgötter, 2013).

Building onto the entrepreneurial orientation construct, Morris and Sexton (1996) introduced the concept of 'entrepreneurial intensity' (EI) and conceptualised it to capture both the degree of entrepreneurial orientation and frequency of entrepreneurship within a given firm. The degree of entrepreneurship refers to the extent to which events occurring within a firm are innovative, risktaking, and proactive. The frequency of entrepreneurship refers to the number of such (innovative, risky, and proactive) events (Kuratko et al., 2011; Scheepers et al., 2007). Intensity can be viewed as a firm's placement along a continuum ranging from conservative to entrepreneurial (Covin, Green \& Slevin, 2006). This means that a firm's performance from the perspective of entrepreneurship at a point in time is shown by its EI score (Kuratko et al., 2011).

Previous research confirms that the degree of entrepreneurship is constituted in terms of three dimensions: innovativeness, risk taking, and proactiveness (Covin et al., 2006; Kuratko et al., 
2011). These dimensions have been extensively documented, and are only briefly delineated here: (1) Innovativeness is the fundamental posture of an entrepreneurial organisation in terms of developing new products or inventing new processes. Innovativeness as an attribute describes an organisations' willingness to add newness with added value. (2) Risk-taking is associated with the willingness to commit significant resources to opportunities and to take calculated business risks. Risk-taking is a commitment to experimentation in the face of uncertainty. (3) Proactiveness is perseverance in ensuring initiatives are implemented, and is concerned with adaptability and tolerance of failure (Covin \& Lumpkin, 2011).

According to Covin et al. (2006), all three dimensions are central to understanding the entrepreneurial process, although they may occur in different combinations, depending on type of entrepreneurial opportunity the firm pursues. Empirical studies among internationalised firms, primarily in developed economies have noted that an entrepreneurial orientation is positively related to firm performance and is essential for firms to discover entrepreneurial opportunities in foreign markets (Covin \& Lumpkin, 2011; Javalgi \& Todd, 2010).

On the basis of above theory and in line with empirical findings suggesting a relationship between EI (to reflect the consolidated nature of the dimensions an aggregate overall EI is used), internationalisation and performance the first hypothesis is formulated where it is anticipated that:

$\mathrm{H}$ 1: Higher levels of entrepreneurial intensity (EI) are positively related to (a) firm performance and (b) internationalisation

\subsection{Entrepreneurial capabilities}

Various theoretical perspectives explain the internationalisation process with reference to capabilities (see Buckley \& Casson, 2009; Oviatt \& McDougall, 2005a). The stage theory of internationalisation suggests that a firm's international operations will gradually increase as it gains knowledge and experience in the international arena and as it develops relationships that cross international boundaries. The resource-based theory expands on the role of resources or lack of them in the internationalisation process, while the network theory looks at how an organisation gains its competitive advantage by developing mutually supportive relationships (Adler \& Kwon, 2002). The organisational learning theory elaborates on the function of knowledge in the effort to globalise a firm, where organisational learning is essential for internationalisation and is in essence a social, interactive process where at the level of the firm, human capital and knowledge is socially embedded and is heavily influenced by social structures (Bauernschuster, Falck \& Heblich, 2010). Based on these different perspectives it is evident that when firms plan to internationalise, resources and various combinations of capabilities are crucial to their success (Bauernschuster et al., 2010; Unger, Rauch, Frese \& Rosenbusch, 2009).

Entrepreneurial capabilities are viewed as a broader range of abilities needed to initiate appropriate action in specific organisational situations and reflect the capacity to initiate and sustain an entrepreneurial dynamism throughout the firm (Obrecht, 2004). Three forms of entrepreneurial capabilities have been identified as distinct competencies which are relevant to developing EI for firms in the international arena, these are: (1) human capabilities - namely foreign institutional knowledge, foreign business knowledge, and internationalisation knowledge; (2) social capabilities - namely social interaction, relationship quality, and network ties; (3) technology capabilities - namely technology distinctiveness and technology acquisition. These sets of capabilities are briefly discussed:

Extensive research shows that human capital and capabilities positively influence entrepreneurship and performance (Unger et al., 2009; Shree \&Urban, 2012). Human capital comprises education, work experience, entrepreneurial experience, and prior knowledge (Unger et al., 2009), which are important stimuli of entrepreneurial alertness, opportunity recognition and exploitation (Shree \& Urban, 2012). Casillas et al. (2009) argue that in an international entrepreneurship context, knowledge allows a clearer understanding of the process of identifying and exploiting opportunities abroad. Knowledge about foreign markets and entrepreneurial 
knowledge is critical to the firm's success in international markets. The acquisition of knowledge allows firms to enhance their learning capabilities, thereby reducing uncertainty and risk, while improving their competitive position.

Social capital and capabilities comprise both the network and the resources that may be mobilised through network activities. Social resources and entrepreneurial networks provide information, create opportunities and enable resources to be accessed (Shree \& Urban, 2012). Jones et al. (2011) position entrepreneurial internationalisation as a complex social phenomenon encompassing borderless resources and networks. To succeed internationally firms must acquire information about foreign markets from external parties, where information about foreign markets is acquired primarily through a firm's social network capabilities. Social capital informs the networking capabilities of firms comprising both strong and weak ties, as implemented by firms with their international partners. Research on social capital finds that relationships among firms with their foreign actors/contacts rather than domestic partners, is important for sustained performance (Shree \& Urban, 2012; Yiu et al., 2007).

Technology and technological capabilities refer to the firm's ability to make effective use of technological knowledge in efforts to assimilate, use, adapt, and change existing technology (Urban, 2010; Zahra, Ireland \& Hitt, 2000). Technology capability within a firm has been identified as an important determinant of innovation and performance, especially when it forms part of a firm's strategic capabilities and is coherent with the firm's strategy, business model, and technological adoptions (Shree \& Urban, 2012). Technological capabilities serve to establish international alliances and enable the firm to assimilate advanced technologies which play a significant role in the internationalisation process (Urban, 2010; Zahra, et al., 2000).

Despite the fact that firms from emerging economies are commonly portrayed as lacking tangible assets and capabilities, evidence is emerging that firms in these markets must possess entrepreneurial capabilities in order to gain greater competitive advantages over existing or potential competitors in the foreign markets (Pangarkar, 2008). An important driver for increasing such international competitiveness is the development of the three key entrepreneurial capabilities that research has identified (Obrecht, 2004; Shree \& Urban, 2012). This line of reasoning culminates in a second hypothesis which focuses on entrepreneurial capabilities thought to influence internationalisation and firm performance (Camisón \& Villar-López, 2010; Obrecht, 2004).

H 2: Higher levels of entrepreneurial capabilities (EC) are positively related to (a) firm performance and (b) internationalisation

\subsection{Internationalisation and environmental influences}

Theory on the environment and its effect on firms are well documented (see for instance, Uzkurt Kumar, Kimzan \& Sert, 2012). Opportunity-rich, munificent environments are driven by demand for new products, dynamism and industry changes, while hostile environments comprise unfavourable change and competitive rivalry (Scheepers et al., 2007). According to Freel (2005) environments are neither certain nor uncertain in themselves but perception makes them so. For instance if individuals perceive an environment to be uncertain they are likely to make decisions that are designed to deal with uncertain environments.

Environmental perceptions are important for EI when considering: (a) the rate of change in industry life cycles, new products, and technology and customer preferences which have increased exponentially; (b) industrial boundaries which are blurring as industries converge or overlap; (c) that a competitive advantage depends on identifying new and emerging opportunities in markets where traditional strategic thinking based on the practices copied from stable industries has long ceased to be effective (Urban, 2010; Uzkurt et al., 2012).

Consequently, the relationship between a firm's EI, levels of internationalisation and performance is likely to be influenced by its external environment (Kuratko et al., 2011). Zahra and George (2002) found firms which aggressively pursued entrepreneurial behaviour in hostile international environments experienced higher returns. Similarly, Wiklund and Shepherd (2003) 
report that the dynamism of the environment moderates the relationship between entrepreneurial behaviour and business performance. Following this direction of research, the third hypothesis predicts that environmental influences will moderate levels of firm EI, EC and their internationalisation and performance, where it is anticipated that:

$\mathrm{H}$ 3: Environmental influences will moderate the relationship between EI, EC and (a) firm performance and (b) internationalisation with the effect that the relationship is more positive when the environment is perceived as more dynamic and hostile.

\section{Methodology}

\subsection{Sampling and data collection}

The research design was cross-sectional, quantitative and survey-based where an online questionnaire was the primary method of data collection. The sampling frame was based on South African firms who already had an international presence (Jones et al., 2011). Given the context of these firms operating from South Africa and in line with previous research parameters, a firm in an emerging market context was considered internationalised when their foreign sales represented a minimum of 10 per cent of total sales or was engaged in exports to more than five countries (Javalgi \& Todd, 2010). Moreover, firms were considered internationalised if they were operating abroad, with either a global presence in exporting, or had opened subsidiaries overseas or had expansions globally (Zahra et al., 2000).

Databases from the Johannesburg Chamber of Commerce and Industry (2008), the Gauteng Chambers of Commerce (2011), and the Department of Trade and Industry (DTI) (DTI, 2013), were all scrutinised as potentially suitable sampling frames. As no comprehensive sampling frame was readily available on internationalised firms in South Africa, it was deemed appropriate to focus on member firms of export councils listed on the DTI website (DTI, 2013). Each export council was requested to circulate the link to the questionnaire to each of their member firms via email. Based on this iterative sampling procedure, a database was obtained which listed firms across a variety of industries and from this consolidated list only firms that met the selection criteria as previously stipulated were selected as respondents. This research procedure ensured that each individual had a numerical identifier (the internet protocol (IP) address and survey number) and contact information, such that each person could be contacted via email.

Using convenience non-probability sampling, managers at the identified firms were targeted who were deemed to be knowledgeable about the internationalisation and export practices within their organisations. This firm level approach is consistent with EI studies where the individual is regarded as a proxy for the firm, and where at the firm level, a managers' self-perception of a firm's strategic orientation represent firm behaviour (Urban, 2010). Based on the sampling selection criteria an initial electronic survey yielded a total of 612 qualifying firms which were coded into a database where a random numbers program was applied to randomly select 50 per cent of these firms (306) as the final sample. This multistage screening rendered a final sample of 117 complete responses, yielding a 38 per cent response rate. This was regarded as a reasonable response rate, given that a number of emails did not reach the recipients presumably due staff mobility, error in capturing email addresses, and/or strict e-mail policy among the firms surveyed (Cooper \& Emory, 1995).

\subsection{The research instrument}

The survey instrument was developed from past theory and empirical findings, which coincide with the main constructs under investigation, these are: (1) EI, (2) EC, (3) environmental influences, (4) internationalisation and (5) firm performance. All of the constructs were treated as higher-level order constructs comprising the different sub-scales as assembled from the literature. The constructs and sub-scales are operationalised in Table 1 as independent, dependent and moderator variables, with the literature support indicated in the last column. 
Table 1

Research instrument scales

\begin{tabular}{|c|c|c|}
\hline Scale & Operationalisation & Literature support \\
\hline $\begin{array}{l}\text { Independent variables: } \\
\text { El: Innovation, risk-taking, } \\
\text { proactiveness sub-scales x } \\
\text { frequency ( } 10 \text { items) }\end{array}$ & $\begin{array}{l}\text { El is a measure of entrepreneurship in a firm that looks at } \\
\text { both the degree and frequency of events with respect to } \\
\text { innovativeness, risk, and proactiveness. Frequency of } \\
\text { entrepreneurship was measured by using summative } \\
\text { measures of these three dimensions as they apply to } \\
\text { entrepreneurial events (associated with multiple events over } \\
\text { time). El can be viewed as a firm's placement along a } \\
\text { continuum ranging from conservative to entrepreneurial. } \\
\text { Measured along a seven-point Likert scale ranging from } \\
\text { 'strongly disagree }=(1) \text { to strongly agree }=(7) \text { '. }\end{array}$ & $\begin{array}{l}\text { Covin \& Lumpkin (2011); Covin } \\
\text { et al. (2006); Kuratko et al. } \\
\text { (2011); Scheepers et al. (2007). }\end{array}$ \\
\hline $\begin{array}{l}\text { EC: Human capability } \\
\text { variables ( } 11 \text { items); social } \\
\text { capability variables ( } 7 \\
\text { items); technology } \\
\text { capability variables ( } 7 \\
\text { items) }\end{array}$ & $\begin{array}{l}\text { EC are measured as a broader range of abilities needed to } \\
\text { initiate appropriate action in specific organisational situations } \\
\text { and reflect the capacity to initiate and sustain an } \\
\text { entrepreneurial dynamism throughout the firm. Three EC } \\
\text { have been identified as distinct competencies purported to } \\
\text { be catalytic to entrepreneurial success in the international } \\
\text { arena, these are: (1) human capital - namely foreign } \\
\text { institutional knowledge, foreign business knowledge, and } \\
\text { internationalisation knowledge; ( } 2 \text { ) social capital - namely } \\
\text { social interaction, relationship quality, and network ties; (3) } \\
\text { technology - namely technology distinctiveness and } \\
\text { technology acquisition. Used same scale as for El. }\end{array}$ & $\begin{array}{l}\text { Bauernschuster et al. (2010); } \\
\text { Camisón \& Villar-López (2010); } \\
\text { Obrecht (2004); Shree \& Urban } \\
\text { (2012); Unger et al. (2009). }\end{array}$ \\
\hline $\begin{array}{l}\text { Dependent variables: } \\
\text { Firm performance: } \\
\text { Financial performance and } \\
\text { growth ( } 6 \text { items); } \\
\text { Internationalisation ( } 3 \\
\text { items) }\end{array}$ & $\begin{array}{l}\text { Firm performance was operationalised as an index of six } \\
\text { commonly used performance measures pertaining to } \\
\text { financial performance and growth. These included items } \\
\text { such as, export profitability, overall profitability, and market } \\
\text { share growth. Firm performance was treated as a perceptive } \\
\text { measure for the past three years (performance over three } \\
\text { years is broad enough time-space to account for seasonal } \\
\text { and cyclical variations in business practices and } \\
\text { performance). Used same scale as for IVs. }\end{array}$ & $\begin{array}{l}\text { Javalgi \& Todd (2010); Steffens } \\
\text { et al. (2009). }\end{array}$ \\
\hline & $\begin{array}{l}\text { Internationalisation was measured by the degree of } \\
\text { international intensity (export intensity), scope of } \\
\text { internationalisation, and speed of internationalisation. In } \\
\text { terms of degree of internationalisation, a firm in an emerging } \\
\text { market context is considered to be internationalised when } \\
\text { their foreign sales represents at least } 10 \% \text { of total sales. } \\
\text { Scope of internationalisation is measured as the number of } \\
\text { countries where firms are operating; in this case the cut-off } \\
\text { was greater than five countries. This variable serves as a } \\
\text { proxy of a firm's global geographic diversity. } \\
\text { Internationalisation speed is measured as the number of } \\
\text { years elapsed between firm foundation and initial entry into } \\
\text { foreign markets. The shorter the time to achieve the export } \\
\text { benchmark (in this case three years from start-up date was } \\
\text { considered significant), the faster in its speed } \\
\text { internationalisation. Measured on ordinal categorical scale. }\end{array}$ & $\begin{array}{l}\text { Chang (2012); Covin \& Lumpkin } \\
\text { (2011); Ge \& Deng (2011); } \\
\text { Jones et al. (2011); Zahra et al. } \\
\text { (2000). }\end{array}$ \\
\hline $\begin{array}{l}\text { Moderator variables: } \\
\text { Environmental influences } \\
\text { include hostility ( } 6 \text { items) } \\
\text { and dynamism ( } 4 \text { items) }\end{array}$ & $\begin{array}{l}\text { The environmental dimensions of hostility and dynamism } \\
\text { were selected due to the modest correlations past research } \\
\text { has found between these two dimensions suggesting that } \\
\text { unique aspects of the environment are captured with each } \\
\text { dimension. Environmental hostility was operationalised as an } \\
\text { unfavourable business climate, such as the intense } \\
\text { competition for resources. Environmental dynamism was } \\
\text { operationalised as both the rate and unpredictability of } \\
\text { change in a specific industry. Used same scale as for IVs. }\end{array}$ & $\begin{array}{l}\text { Scheepers et al. (2007); Uzkurt } \\
\text { et al. (2012); Zahra et al. (2000). }\end{array}$ \\
\hline
\end{tabular}

The measures used were selected from past studies where in most cases instrument validity and reliability has already been established and which confirms that: (1) the EI factor structure is consistent with the three theoretically derived dimensions (Covin \& Lumpkin, 2011); (2) EC is a multi-dimensional measure comprising human, social and technological factors (Camisón \& Villar-López, 2010); (3) the environmental scale comprises two main factors which reflect the distinct sub-scales of environmental hostility and dynamism with discriminant and convergent 
validity previously established (Scheepers et al., 2007; Zahra et al., 2000); and (4) the internationalisation and (5) performance indicators have been shown to have acceptable criterionrelated validity using a range of both categorical and continuous criterion variables (Steffens, Davidsson \& Fitzsimmons, 2009).

In line with past studies control variables were included where the theoretical importance of firm age, size, and industry in relation to performance has been reported to be significant (Urban, 2010). It seems older firms are less entrepreneurial, while large firms are seen to possess resource slack and capabilities to overcome foreign market barriers and have a performance edge over their smaller counter parts (Javalgi \& Todd, 2010).

As a precaution, common method response bias was methodologically controlled for by gathering data representing the IV, MV and DV at different time periods ( 2 week intervals) and by counterbalancing the question order. Safeguarding respondent anonymity also ensured to some extent that social desirability and item ambiguity were avoided (Podsakoff et al., 2003). Moreover, to establish the psychometric properties of the various scales instrument validity and reliability were tested.

\subsection{Data analysis}

Descriptive and inferential statistics were calculated using the STATISTICA software system, version 10 (StatSoft, 2011). To test the hypotheses hierarchical regression analysis was used to determine the contribution of the variables in terms of their prediction value. Given the multi-level dimensionality of the constructs, level 1,2, and 3 analyses are shown in the results section, however the hypotheses are only discussed in terms of the higher-level (1) formulation to allow for general explanations using the main constructs. For example, EI is considered a level 1 construct and is measured by jointly considering the subscales of innovation, risk-taking and proactiveness, as well as the frequency of entrepreneurship accounted for in this construct.

\section{Results}

\subsection{Sample characteristics}

The results reveal relative heterogeneity in the sample characteristics, where in terms of firm size, 51 per cent of firms had more than 250 employees, while 23 per cent had between 51 and 250 employees, and 26 per cent had up to 50 employees. In terms of firm age, the majority of firms (40 per cent) were founded between the years 1951-1990, while 20 per cent were founded between the years 1991-000. Approximately one in four (26 per cent) of the firms were founded before 1950, while only 15 per cent were founded after the year 2000. Other highlights include that 38 per cent of the firms went the internationalisation route within three years of their start-up date, while cumulatively, 58 per cent of firms were internationalised by six years of age and almost threequarters ( 74 per cent) were internationalised by the age of 10 years. Almost three-quarters of the firms ( 73 per cent) exported to more than 5 countries, while 27 per cent of the firms exported to less than 5 countries. Out of these exports, 27 per cent exported to 6-10 countries, while 27 exported to 11-20 countries, and only 11 per cent of the firms exported to more than 20 foreign countries. Lastly in terms of sampling parameters, 88 per cent of firms had export sales contributing to at least 10 per cent of their total revenues. Over half of the firms (53 per cent) had export sales contributing to at least 25 per cent to their total revenues, while of only one in five firms ( 20 per cent) over 75 per cent of their total sales were derived from exports.

\subsection{Scale validity and reliability tests}

The study used exploratory factor analysis (EFA) to determine the validity of the theoretically derived scales, since the aim was to search for or refine the fundamental constructs or dimensions assumed to underlie the variables. In terms of the EFA results, Bartlett's test of sphericity yielded significant $(\mathrm{p}<0.001)$ Chi-Square values and satisfactory Kaiser-Meyer-Olkin (KMO) measures 
of sampling adequacy $(>0.80)$ for the different scales indicating sufficient correlations amongst the variables. Component analysis and orthogonal rotation methods were used, where factors with eigenvalues $\geq 1$ and factor loadings $\geq 0.60$, were considered significant (Hair Black, Babin \& Anderson, 2010). EFA results for the EI scale yielded three eigenvalues greater than one and showed nine items loading relatively high $(\geq 0.75)$ onto each of the scale dimensions which was intuitively and conceptually suitable. Similarly, for the EC scale the eigenvalue summary showed that a four factor solution was most suitable for determining the validity of this scale. Even though the theoretically constructed scale consisted of three dimensions, the technology dimension was reconstructed by separating items into two distinct factors as per the factor results. EFA results for the scale for environmental influences rendered two main factors $(\geq 0.65)$ which reflect the distinct sub-scales of environmental hostility and dynamism. In terms of the firm performance scale, the eigenvalue summary revealed that a one factor solution was suitable to measure this construct, where this one factor had an eigenvalue of 3.93, and explained 65.4 per cent of the variance. Consequently, the firm performance scale was aggregated by summing the measurement items at the level 1 construct level for subsequent hypothesis testing. Similarly, the three single-item measures of internationalisation performance - speed, scope and intensity were combined into a composite measure with a view towards developing a single measure of internalisation performance independent of the firm performance scale. As each of these three variables was measured on an ordinal categorical scale, three sets of one-way Analyses of Variance (ANOVA) were computed using these measures as independent variables. The direction of their means was checked across the levels of all variables involved in the case of significant effects. Four significant effects were found on export intensity, in terms of the proactiveness and foreign institutional knowledge dimensions as well as in terms of interactions of EC with hostility and EC with dynamism. Additionally, the means of the proactiveness and foreign institutional knowledge dimensions, when plotted across the groups ordered on export intensity, were consistent in terms of order and direction indicating sufficient evidence to retain export intensity as a single measure of internationalisation.

Reliability analysis was conducted on all of the separate scales, where satisfactory Cronbach's alphas $(>0.70)$ were obtained for the different scales with interitem correlations exceeding the minimum guideline score for adequate internal consistency reliability of 0.30 (Hair et al., 2010). See Table 2 for a fullset of reliability results and dimensionality of the factors obtained through EFA. (When considering the large number of constructs, sub-scales and corresponding items at different measurement levels only the variable levels and their corresponding scale reliabilities are shown in Table 2).

Table 2

Reliability measures of the scales and subscales

\begin{tabular}{|l|l|c|c|c|c|}
\hline \multicolumn{1}{|c|}{ Factors } & \multicolumn{1}{|c|}{ Dimensions } & $\begin{array}{c}\text { Variable } \\
\text { type }\end{array}$ & $\begin{array}{c}\text { Variable } \\
\text { LEVEL }\end{array}$ & $\begin{array}{c}\text { Cronbach } \\
\text { alpha }\end{array}$ & $\begin{array}{c}\text { Average inter- } \\
\text { Item } \\
\text { correlation }\end{array}$ \\
\hline EI & EI & IV & 1 & 0.88 & 0.31 \\
\hline EC & EC & IV & 1 & 0.93 & 0.38 \\
\hline Environmental Hostility & Environmental Hostility & Moderator & 2 & 0.74 & 0.33 \\
\hline Environmental Dynamism & Environmental Dynamism & Moderator & 2 & 0.72 & 0.30 \\
\hline EI & El & IV & 2 & 0.86 & 0.35 \\
\hline Human capability & Frequency of entrepreneurship & IV & 2 & 0.76 & 0.45 \\
\hline Social capability & Human capability & IV & 2 & 0.93 & 0.57 \\
\hline Technological capability & Social capability & IV & 2 & 0.84 & 0.44 \\
\hline Firm performance & Technology & IV & 2 & 0.86 & 0.55 \\
\hline Firm performance & Growth & DV & 3 & 0.80 & 0.60 \\
\hline & Financial & DV & 3 & 0.80 & 0.58 \\
\hline
\end{tabular}

continued/ 


\begin{tabular}{|l|l|c|c|c|c|}
\hline \multicolumn{1}{|c|}{ Factors } & \multicolumn{1}{|c|}{ Dimensions } & $\begin{array}{c}\text { Variable } \\
\text { type }\end{array}$ & $\begin{array}{c}\text { Variable } \\
\text { LEVEL }\end{array}$ & $\begin{array}{c}\text { Cronbach } \\
\text { alpha }\end{array}$ & $\begin{array}{c}\text { Average inter- } \\
\text { Item } \\
\text { correlation }\end{array}$ \\
\hline \multirow{3}{*}{ EI } & Innovativeness & IV & 3 & 0.75 & 0.44 \\
& Pro-activeness & IV & 3 & 0.79 & 0.47 \\
& Risk-taking & IV & 3 & 0.75 & 0.45 \\
\hline \multirow{3}{*}{ Human capability } & Foreign institutional knowledge & IV & 3 & 0.80 & 0.59 \\
& Foreign business knowledge & IV & 3 & 0.87 & 0.63 \\
\hline \multirow{3}{*}{ Social capability } & Internationalisation knowledge & IV & 3 & 0.92 & 0.75 \\
\hline \multirow{2}{*}{ Technology } & Social interaction & IV & 3 & 0.76 & 0.63 \\
& Relationship quality & IV & 3 & 0.80 & 0.58 \\
& Network ties & IV & 3 & 0.88 & 0.78 \\
\hline
\end{tabular}

\subsection{Hypotheses testing}

Mean scores of the scales and subscales were relatively high and the skewness index (SI) and the kurtosis index (KI) were not severe. The relatively high mean scores suggest that the responses to these scales are generally positive, where for instance the EI scale reflects a mean score of 5.69 (17 Likert scale). Additionally the standard deviations of certain scores exceeds 1.00 , suggesting relatively high variation across the responses.

To understand the nature of the relationship between the variables, a correlation analysis was conducted. Pearson product-moment correlations coefficients were calculated for each of the scales and are reported with levels of significance as denoted in Table 3. Several relatively strong $(r>0.70)$ and positive correlations among the EI sub-scales were observed but these were anticipated as they represent the sub-scales of the higher-level EI construct. Additionally many significant correlations are evident across the majority of the variables at the 95 and 99 per cent confidence levels.

The first two sets of hypotheses posited a bivariate relationship and therefore the test of the $\mathrm{H}$ 1(a) (b) and H 2 (a) (b) was initially analysed on the basis of the correlation matrix (refer to Table 3). Several scatter plots were also drawn up but are not shown due to space limitations. In the first instance for $\mathrm{H} 1$ (a) a significant correlation $(\mathrm{r}=0.27, \mathrm{p}<0.01)$ was noted between EI and firm performance. Even though this relationship is positive and relatively weak the results do provide some initial support for H1 (a). In terms of H1 (b), EI was positively related to internationalisation with a significant correlation coefficient $(\mathrm{r}=0.23, \mathrm{p}<0.05)$. Although this relationship is positive relatively weak, the results do provide some initial support for $\mathrm{H} 1$ (b).

Table 3

Correlation matrix for variables under study

\begin{tabular}{|c|c|c|c|c|c|c|c|c|c|c|c|c|}
\hline Variables & 1 & 2 & 3 & 4 & 5 & 6 & 7 & 8 & 9 & 10 & 11 & 12 \\
\hline $1 \mathrm{EI}$ & 1 & $0.85^{*}$ & $0.83^{*}$ & $0.73^{*}$ & $0.56^{*}$ & $0.47^{*}$ & $0.49^{*}$ & $0.39^{*}$ & 0.17 & 0.08 & $0.27^{\star \star}$ & $0.23^{*}$ \\
\hline 2 Innovativeness & & 1 & $0.67^{*}$ & $0.50^{*}$ & $0.40^{*}$ & $0.38^{*}$ & $0.32^{*}$ & $0.27^{\star}$ & 0.14 & 0.08 & 0.11 & $0.19^{*}$ \\
\hline 3 Proactiveness & & & 1 & $0.39^{*}$ & $0.45^{\star}$ & $0.41^{*}$ & $0.35^{*}$ & $0.30^{*}$ & 0.05 & 0.00 & 0.16 & $0.33^{* *}$ \\
\hline 4 Risk-taking & & & & 1 & $0.32^{*}$ & $0.27^{*}$ & $0.34^{\star}$ & 0.16 & $0.21^{*}$ & 0.09 & 0.27 & $0.13^{* *}$ \\
\hline 5 EC & & & & & 1 & $0.89^{*}$ & $0.78^{*}$ & $0.73^{*}$ & 0.05 & 0.13 & $0.42^{* *}$ & $0.19^{*}$ \\
\hline 6 Human capability & & & & & & 1 & $0.56^{*}$ & $0.47^{*}$ & 0.08 & 0.06 & $0.28^{* *}$ & $0.23^{*}$ \\
\hline 7 Social capability & & & & & & & 1 & $0.38^{*}$ & 0.02 & $0.18^{*}$ & $0.42^{\star \star}$ & $0.24^{*}$ \\
\hline 8 Technological capability & & & & & & & & 1 & 0.01 & 0.10 & $0.35^{\star \star}$ & 0.04 \\
\hline 9 Environmental hostility & & & & & & & & & 1 & 0.07 & $0.22^{*}$ & 0.06 \\
\hline 10 Environmental dynamism & & & & & & & & & & 1 & $0.19^{*}$ & 0.17 \\
\hline 11 Firm performance & & & & & & & & & & & 1 & 0.03 \\
\hline 12 Internationalisation & & & & & & & & & & & & 1 \\
\hline
\end{tabular}


For $\mathrm{H} 2$ (a) a significant correlation $(\mathrm{r}=0.42, \mathrm{p}<0.001)$ between $\mathrm{EC}$ and firm performance was observed, suggesting that higher levels of EC evident at a firm, translate into higher levels of firm performance. The relationship is positive and relatively strong where the results provide initial support for $\mathrm{H} 2$ (a). For $\mathrm{H} 2$ (b), a significant correlation $(\mathrm{r}=0.19, \mathrm{p}<0.05)$ between $\mathrm{EC}$ and internationalisation was also noted. This relationship is positive but relatively weak with the results providing some initial support for $\mathrm{H} 2$ (b).

Hierarchical multiple regression was then used to test the hypotheses. The regression equation formulated for the base model as well for the model including the moderator, at the higher-level order of constructs, are delineated as:

Regression equation (base model): Int $=\left(b_{0}+\beta_{l} \mathrm{EI}+\beta_{2} \mathrm{EC}+\beta_{3} \mathrm{EIxEC}\right)$. Perf $=\left(b_{0}+\beta_{l} \mathrm{EI}+\right.$ $\left.\beta_{2} \mathrm{EC}+\beta_{3} \mathrm{EIxEC}\right)$. Regression equation (including moderator): $\mathrm{Int}=\left(b_{0}+\beta_{1} \mathrm{EI}+\beta_{2} \mathrm{EC}+\beta_{3} \mathrm{EIxEC}\right.$ $\left.+\beta_{4} \mathrm{EH}+\beta_{5} \mathrm{ED}\right)$, Perf $=\left(b_{0}+\beta_{1} \mathrm{EI}+\beta_{2} \mathrm{EC}+\beta_{3} \mathrm{EIxEC}+\beta_{4} \mathrm{EH}+\beta_{5} \mathrm{ED}\right)$.

Where:

$\beta_{1}$ is the regression weight of EI as the predictor of internationalisation (Int) and performance (Perf).

$\beta_{2}$ is the regression weight of the EC as the predictor of internationalisation (Int) and performance (Perf). $\beta_{3}$ is the regression weight of the interaction between EI and EC as the predictors of internationalisation (Int) and performance (Perf). $\beta_{4}$ is the regression weight of environmental hostility $(\mathrm{EH})$ as the moderator of the relationship between EI, EC and internationalisation (Int). $\beta_{5}$ is the regression weight of environmental dynamism (ED) as the moderator of the relationship between EI, EC and performance (Perf).

To run the regression model, the centring of the predictors was carried out by using the grand mean as a pivotal point, and the interaction variable was formulated by multiplying the centred predictor variables together. In order to accommodate the tests of the two DVs, an initial regression model was tested in two separate steps, with the first model having firm performance as the DV, and the second model having internationalisation as the DV. (As per the EFA results, firm performance was treated as a composite factor and internationalisation is represented by the export intensity factor). The constructs were then individually tested for their predictive power to the model in terms of each separate hypothesis and then, in the case of multiple regression analysis, all the predictors were included in the model simultaneously to check whether the regression weights are similar in the presence of other variables. Using this method, specification error is controlled for by including only relevant variables in the model and excluding irrelevant variables (Cooper \& Emory, 1995).

Multiple regression analysis was also used to test $\mathrm{H} 3$ where it was predicted that environmental influences would moderate the relationship between EI, EC, and (a) firm performance and (b) internationalisation to the effect that the relationship is more positive[H1] when the environment is perceived as more dynamic and hostile.

To systematically test $\mathrm{H} 3$ at the level 1 , level 2, and level 3 of measurement, a base model as well as the moderated model were calculated. However only the combined model results are displayed and discussed which is limited to the number of factors that provide the highest level of interpretability in line with the theoretical constructs and stated hypothesis. For the firm performance model, in terms of the results for the base model - see Table 4, when all the factors were included simultaneously, an overall significant $B=8.67$ and F-value of $4,112(\mathrm{p}<0.001)$ were obtained with a regression coefficient of $\mathrm{R}^{2}=0.236$. The highest beta weight for EC was 0.325 $(p<0.01)$. While these results show that this direct effects model explains only 23.6 per cent of firm performance, when considering the moderator model a minimal change in the $\mathrm{R}^{2}$ of 0.027 ( 2.7 per cent) increase was noted as the moderators were included. EC was the only significant variable in the moderated model $(\beta=0.328, \mathrm{p}<0.01)$ when both environmental hostility and dynamism were included as moderators, offering only partial support for $\mathrm{H} 3$ (a).

In terms of the internationalisation model, when all the factors were entered simultaneously, no significant predictors emerged. Full results are presented for both the base model and moderator in Table 5. The base model shows an overall significant $B=2.47$ and $F$-value of $4.112(\mathrm{p}<0.05)$, with a 
regression coefficient of $\mathrm{R}^{2}=0.080$. In the moderator model there was only a minimal change in the $\mathrm{R}^{2}$ of 0.059 (5.9 per cent) increase when the moderators were included, while the moderation effect of all the moderator variables was not significant. The presence of the other predictors did not adversely influence the stability of the regression weights, and hence did not affect the predicted relationship. Consequently no support was evident for H3 (b).

Table 4

Regression results for the firm performance model with all variables entered simultaneously

\begin{tabular}{|c|c|c|c|c|c|c|}
\hline \multirow{2}{*}{$\begin{array}{c}\text { LEVEL } 1 \\
\text { Firm performance }\end{array}$} & \multicolumn{3}{|c|}{ Base model } & \multicolumn{3}{|c|}{ Including Moderator } \\
\hline & B & SE & Beta (B) & B & SE & Beta (ß) \\
\hline Intercept & 1.262 & 1.019 & & -3.313 & 5.847 & \\
\hline $\mathrm{EI}$ & 0.194 & 0.177 & 0.112 & 0.970 & 1.000 & 0.562 \\
\hline EC & 0.524 & 0.163 & $0.325^{\star *}$ & 0.529 & 0.164 & $0.328^{* *}$ \\
\hline Environmental hostility & -0.253 & 0.099 & $0.216^{*}$ & 0.956 & 0.782 & 0.817 \\
\hline Environmental dynamism & 0.160 & 0.110 & 0.121 & -0.127 & 0.970 & -0.096 \\
\hline El*dynamism & & & & 0.052 & 0.163 & 0.274 \\
\hline EC dynamism & & & & 0.095 & 0.126 & 0.233 \\
\hline El*hostility & & & & -0.207 & 0.133 & -1.255 \\
\hline EC*hostility & & & & -0.049 & 0.113 & -0.134 \\
\hline R2 base & 0.236 & & & & & \\
\hline$\Delta \mathrm{R} 2$ & 0.027 & & & & & \\
\hline$F(4,112)$ base & $8.67^{\star \star *}$ & & & & & \\
\hline$F(8,108)$ with moderator & $4.84^{\star \star *}$ & & & & & \\
\hline
\end{tabular}

Table 5

Regression results for the internationalisation model with all variables entered simultaneously

\begin{tabular}{|c|c|c|c|c|c|c|}
\hline \multirow{2}{*}{$\begin{array}{l}\text { LEVEL } 1 \\
\text { Internationalisation }\end{array}$} & \multicolumn{3}{|c|}{ Base model } & \multicolumn{3}{|c|}{ Including Moderator } \\
\hline & B & SE & Beta (ß) & B & SE & Beta (ß) \\
\hline Intercept & -0.479 & 1.117 & & 5.105 & 6.319 & \\
\hline El & 0.289 & 0.194 & 0.167 & -0.668 & 1.081 & 0.387 \\
\hline EC & 0.129 & 0.179 & 0.080 & 0.129 & 0.177 & 0.080 \\
\hline Environmental hostility & 0.047 & 0.109 & 0.040 & -0.993 & 0.846 & -0.848 \\
\hline Environmental dynamism & 0.192 & 0.120 & 0.145 & 0.116 & 1.049 & 0.088 \\
\hline El*dynamism & & & & 0.012 & 0.176 & 0.065 \\
\hline EC*dynamism & & & & 0.024 & 0.137 & 0.059 \\
\hline El*hostility & & & & 0.177 & 0.144 & 1.069 \\
\hline EC*hostility & & & & $\overline{-} .097$ & 0.122 & -0.264 \\
\hline $\mathrm{R} 2$ base & 0.080 & & & & & \\
\hline$\Delta \mathrm{R} 2$ & 0.059 & & & & & \\
\hline$F(4,112)$ base & $2.47^{*}$ & & & & & \\
\hline $\mathrm{F}(8,108)$ with moderator & $2.20^{*}$ & & & & & \\
\hline
\end{tabular}

\section{Discussion}

This article contributes to the international entrepreneurship research stream by analysing the relationship between variables hypothesised to influence firm performance and internationalisation, while at the same time considering environmental influences. The article has paved the way to expand on the EI and EC constructs in terms of their influence on internationalisation and firm performance. The results offer fresh insights and open new research paths to understanding EI and EC as enablers to internationalisation and performance in an emerging market context. 
Overall the results of the article provide some empirical support insofar as EI and EC are positively related to internationalisation and performance, but this relationship seems not to be influenced by environmental dynamism and hostility. Perhaps the sample of firms assembled for this study display higher levels of EI and EC when engaging in international markets without environmental hostility and dynamism being significant determinants in this relationship.

However, the results do provide support for $\mathrm{H} 1$, where the frequency and degree of entrepreneurial orientation, as captured by the EI construct, is related to firm performance, and where EI is also significantly related to internationalisation. This means that in order to achieve higher levels of performance as captured through financial success and growth, firms tend to have higher levels of EI as measured by innovativeness in products and serves, risk-taking, and proactiveness. Similarly, to internationalise as measured through achieving higher foreign sales, firms have to display higher levels of EI by proactively innovating new products for their international markets in order to boost foreign sales. When combined with the internationalisation literature, it seems the development of EI requires organisational members to engage in proactive activities such as spending time abroad and attending foreign trade fares in search of new opportunities in order to enhance firm performance (Jones et al., 2011; Shree \& Urban, 2012). These results confirm that EI has positive performance implications and may assist firms in seeking out new opportunities internationally. Recognising that opportunities through which a firm can expand are likely to be found in the global market rather than in its domestic environment, firms from South Africa should seek to develop a position that is consistent with higher levels of EI in order to pursue such opportunities abroad.

In terms of $\mathrm{H} \mathrm{2}$, the study found that EC is positively related to internationalisation and firm performance. Different sets of capabilities enable management to take appropriate actions in specific organisational situations to initiate and sustain an entrepreneurial dynamism throughout the organisation. Although EC was analysed only at the higher-level order construct, the results are in line with existing literature which show that human-, social- and technology-based capabilities are important predictors for successful internationalisation (Bauernschuster et al., 2010). These findings imply that social capital provides compensating advantages (for technology and human capital) in order to compete successfully in markets abroad. Moreover, the internationalisation of a firm is driven by managers with strategic and operational knowledge of global markets, where in particular the dimensions of technological learning (breadth, depth and speed) can enhance the internationalisation process. Rapid internationalisation means high levels of competition, electronic commerce, economies of scale, more demanding customers and longer distance to end-customers. This forces firms to enhance their learning capabilities (Oviatt \& McDougall, 2005a), as knowledge is essential to assisting the internationalisation process, especially where technological advances render this process more efficient (Zahra et al. 2000).

There was partial support for H3 where weak evidence was found for environmental hostility moderating the relationship between EI and performance, but no evidence was detected for environmental dynamism. Moreover both environmental dynamism and hostility were found not to influence EI and EC in terms of internationalisation. Consequently in an environment perceived to be characterised by dynamism, EI and EC were not positively associated with either firm performance or internationalisation. This result is somewhat surprising when the linkage between EI and performance appears to be stronger for firms that operate in increasingly dynamic or turbulent environments. Moreover, past research finds that firms that aggressively pursued entrepreneurial behaviour in international environments with higher levels of hostility experienced higher returns (Uzkurt et al., 2012). A plausible explanation for this anomaly may be that in dynamic international environments exporting firms may simply scale down their efforts in those markets and focus on alternative markets. International diversification is often used as a strategy that enables firms to generate the resources necessary to support projects, spread the risk and provide additional market penetration (Camisón \& Villar-López, 2010). Another explanation may be that when surveying environmental perceptions, there is concern that these perceptions may not reflect the objective attributes of the actual environment. Managers' perceptions of their 
environments do not always reflect the objective qualities of their markets and industries. Such mismatch may arise from ineffective competitive analyses, poor environmental analyses, cognitive biases, or managerial hubris (Zahra et al., 2000).

Considering the context of the study, research in emerging markets like South Africa may be considered as valuable, as very few empirical studies have been previously conducted that focus on EI, EC and internationalisation. It has been shown in other domains, such as strategy, that researchers should not assume that findings in a developed economy will be equally applicable to an emerging economy (Bruton et al., 2008). Clearly there is a need to develop an understanding of $\mathrm{EI}$ and EC differences and their impacts on internationalisation and performance in such different contexts. The importance of further examining EI and EC in emerging country contexts is valuable since such investigations allow researchers to compare and evaluate different processes and attributes linked to these constructs, which firms may use in similar environmental contexts. Additionally by conducting research on EI in emerging market contexts the relevance of firmbased entrepreneurial behaviour as opposed to only focusing on independent start-ups is highlighted.

It is also useful to note that the characteristics of the sample assembled for this article may have influenced the results. Similar to other international entrepreneurship research (Javalgi \& Todd, 2010), the majority of the firms sampled in the present study were high-technology firms (65 per cent) operating in the manufacturing industry ( 47 per cent). Such a high concentration of firms in the high-technology sector may be indicative of the shortening window of opportunities that are available to these firms as a result of the dynamism facing this sector domestically. Consequently, industries and sectors with rapid changes in technology and shorter product life cycles may naturally lead firms towards internationalisation. Another interesting observation regarding the study sample is that approximately 20 per cent of the firms had over 75 per cent of sales geared towards exports, with over half of the firms indicating export sales contributing at least 25 per cent towards total sales. This is an encouraging finding as prior research demonstrates that firms that achieve significant export sales, despite resource constraints across the value chain and other administrative challenges which are often typical in emerging economies, show increased levels of performance (Camisón \& Villar-López, 2010).

\subsection{Implications and recommendations}

Several practical implications and recommendations emerge from the study, where it is suggested that:

- Firms in a similar context to South Africa are encouraged to increase their levels of EI as a viable strategic orientation to enhance their exporting capabilities and overall firm performance

- South Africa needs to improve its international competitiveness by channelling risk capital towards internationalised firms with higher levels of entrepreneurial capabilities in terms of human, social and technology factors

- South African exporting firms must strive to develop a combination of different capabilities which can then lead to specific benefits towards increasing their foreign market share

- Policy makers in business, government and educational institutions should put more emphasis on programs that foster the development of EI and EC among internationalised firms

\subsection{Limitations and future research}

The study has several limitations which open up avenues for future research. The cross-sectional design of the study prevents any causal relationships among the variables to be asserted, which requires a longitudinal study to establish the hypothesised links. The study also relied on perceptual data where responses may have been influenced by perceptual biases and cognitive limitations. Moreover, since environmental conditions vary significantly from one industry to another, and because the nature of the environmental characteristics is inextricably linked to the 
stage of the industry's evolution, future research could investigate industry-specific exporting initiatives. Another direction for future research is the possibility of reverse causality as an increase in internationalisation and performance may also affect levels of EI and EC. Consequently, future research should utilise more dynamic models and examine reverse causality and simultaneity when investigating these variables. Finally, future research efforts that focus on organisational learning that may affect the development of entrepreneurial behaviour in a firm in order to strengthen existing competitive capabilities and build new competitive capabilities may also prove useful.

\subsection{Conclusion}

The article makes a contribution to research by examining the influence of EI and EC on firm internationalisation and performance in an emerging market context. Two strands of theory, internationalisation and entrepreneurship where used to unpack the relationship between EI, EC and internationalisation and performance, while considering the moderating effect of environmental hostility and dynamism. Given the dynamic nature of global trade, and the increasing reliance of firms in emerging economies to internationalise, it remains vital to continue researching how entrepreneurship and fostering productive capabilities influence performance, while considering the unique characteristics of the environment in which these firms operate.

\section{References}

ADLER, P.S. \& KWON, S.W. 2002. Social capital: The good, the bad, and the ugly, In Eric, L.L. (ed.) Knowledge and social capital. Boston: Butterworth-Heinemann:89-115.

BAUERNSCHUSTER, S., FALCK, O. \& HEBLICH, S. 2010. Social capital access and entrepreneurship. Journal of Economic Behavior \& Organization, 76(3):821-833.

BRUTON, G.D., AHSTROM, D. \& OBLOJ, K. 2008. Entrepreneurship in emerging economies: Where are we today and where should the research go in the future. Entrepreneurship Theory and Practise, January: $1-14$.

BUCKLEY, P.J. \& CASSON, M.C. 2009. The internalisation theory of the multinational enterprise: A review of the progress of a research agenda after 30 Years. Journal of International Business Studies, 40 : 1563-1580.

CAMISÓN, C. \& VILLAR-LÓPEZ, A. 2010. Effect of SMEs' international experience on foreign intensity and economic performance: The mediating role of internationally exploitable assets and competitive strategy. Journal of Small Business Management, 48(2):116-151.

CARMODY, P. 2012. Another BRIC in the wall? South Africa's developmental impact and contradictory rise in Africa and beyond. European Journal of Development Research, 24(2):223-241.

CASILLAS, J.C., MORENO, A.M., ACEDO, F.J., GALLEGO, M.A. \& RAMOS, E. 2009. An integrative model of the role of knowledge in the internationalization process. Journal of World Business, 44(3):311-322. CHANG, J. 2012. Antecedents of MNE performance: Evidence from Asia Pacific emerging markets. International Journal of Business and Emerging Markets, 4(1):69-88.

COOPER, D.R. \& EMORY, C.W. 1995. Business research methods. Chicago: Irwin.

COVIN, J.G. \& LUMPKIN, G. 2011. Entrepreneurial orientation theory and research: Reflections on a needed construct. Entrepreneurship Theory and Practice, 35:855-872.

COVIN, J.G., GREEN, K.M. \& SLEVIN, D.P. 2006. Strategic process effects on the entrepreneurial orientation-sales growth rate relationship. Entrepreneurship Theory and Practice, 30(1):57-81.

CUYVERS, L., DUMONT, M., VIVIERS, W., DE PELSMAKER, P., MULLER, M.L., JEGERS, M., SAAYMAN, A. 2008. Export intensity and the competitive intelligence of exporting companies: Evidence from South Africa. South African Journal of Economic and Management Sciences, 11(1):85-97.

DEPARTMENT OF TRADE AND INDUSTRY (DTI). 2013. SMME development strategy. Available at: http://www.thedti.gov.za/news2013/ [accessed 2013-04-21].

FREEL, M.S. 2005. Perceived environmental uncertainty and innovation in small firms. Small Business Economics, 25:49-64. 
GAMMELTOFT, P. PRADHAN, J.P. \& GOLDSTEIN, A. 2010. Emerging multinationals: Home and host country determinants and outcomes. International Journal of Emerging Markets, 5(3/4):254-265.

GAUTENG CHAMBERS OF COMMERCE. 2011. Gauteng Chambers. Available at: http://www.2bbusiness.co.za/info/chambers-of-commerce/gauteng-chambers/ [2011-11-14].

GE, G. L. \& DENG, D. Z. 2011. Determinants of internationalisation strategies: A study of Chinese multinational enterprises. International Journal of Business and Emerging Markets, 3(2):137-157.

GOLDSTEIN, A., 2007. Multinational companies from emerging economies: composition, conceptualization and direction in the global economy. Basingstoke: Palgrave.

HAIR, J.F., BLACK, W.C., BABIN, B.J. \& ANDERSON, R.E. (eds.) 2010. Multivariate data analysis: A global perspective ( $7^{\text {th }}$ ed.) Upper Saddle River, NJ: Pearson.

HANSEN, J.D., DEITZ, G.D., TOKMAN, M., MARINO, L.D. \& WEAVER, K.M. 2011. Cross-national invariance of the entrepreneurial orientation scale. Journal of Business Venturing, 26(1):61-78.

HOSKISSON, R.E., EDEN, L., LAU, C.M. \& WRIGHT, M., 2000. Strategizing in emerging economies. Academy of Management Journal, 43:249-267.

JAVALGI, R.G. \& TODD, P.R. 2010. Entrepreneurial orientation, management commitment, and human capital: The internationalization of SMEs in India. Journal of Business Research, 64(9):1004-1010.

JOHANNESBURG CHAMBER OF COMMERCE AND INDUSTRY. 2008. Regions, affiliates and members JCCI. Available at: http://www.jcci.co.za/members/ [accessed 2011-11-18].

JONES, M.V., COVIELLO, N. \& TANG, Y.K. 2011. International entrepreneurship research (1989-2009): A domain ontology and thematic analysis. Journal of Business Venturing, 26(6):632-659.

KURATKO, D., MORRIS, M. \& COVIN, J. (eds.) 2011. Corporate entrepreneurship \& innovation. ( $3^{\text {rd }}$ ed.) Library of Congress: South Western, Cengage Learning.

LIU, Y., LI, Y. \& XUE, J. 2011. Ownership, strategic orientation and internationalization in emerging markets. Journal of World Business, 46:381-393.

LYON, D.W., LUMPKIN, G.T. \& DESS, G.G. 2000. Enhancing entrepreneurial orientation research: Operationalizing and measuring a key strategic decision making process. Journal of Management, 26(5): 1055-1085.

MANOLOVA, T.S., MANEV, I.M. \& GYOSHEV, B.S. 2010. In good company: The role of personal and inter-firm networks for new-venture internationalization in a transition economy. Journal of World Business, 45(3):257-265.

MORRIS, M.H. \& SEXTON, D.L. 1996. The concept of entrepreneurial intensity: implications for company performance. Journal of Business Research, 36(1):5-13.

OBRECHT, J.J. 2004. Entrepreneurial capabilities: A resource-based systematic approach to international entrepreneurship. Handbook of Research on International Entrepreneurship, 248-264.

OVIATT, B.M. \& MCDOUGALL, P.P. 2005a. Toward a theory of international new ventures, Journal of International Business Studies, 36(1):29-41.

OVIATT, B.M. \& MCDOUGALL, P.P. 2005b. Defining international entrepreneurship and modelling the speed of internationalization. Entrepreneurship Theory and Practice, 29(5):537-554.

PANGARKAR, N. 2008. Internationalization and performance of small- and medium-sized enterprises. Journal of World Business, 43(4):475-485.

PODSAKOFF, P., MACKENZIE, S., LEE, J. \& PODSAKOFF, N. 2003. Common method biases in behavioural research: A critical review of the literature and recommended remedies. Journal of Applied Psychology, 88:879-903.

RIPOLLÉS-MELIÁ, M., MENGUZZATO-BOULARD, M. \& SÁNCHEZ-PEINADO, L. 2007. Entrepreneurial orientation and international commitment. Journal of International Entrepreneurship, 5(3-4):65-83.

SCHEEPERS, M., HOUGH, J. \& BLOOM, J. 2007. Entrepreneurial intensity: A comparative analysis of established companies in South Africa, South African Journal of Economic Management Sciences, 10(2): 238-255.

SHREE, S. \& URBAN, B. 2012. The role of capital factors in internationalisation: An emerging market focus. Teorija Ir Praktika (Business Theory and Practice, 13(4):292-303. 
SINGH, D.A. 2009. Export performance of emerging market firms. International Business Review, 18(4): 321-330.

SONG, M., WANG, T. \& PARRY, M.E. 2010. Do market information processes improve new venture performance? Journal of Business Venturing, 25:556-568.

STATSOFT. 2011. StatSoft Inc. Statistica. Available at: file://localhost $/<$ http/:: www.statsoft.com .aspx $>$ [accessed 2012-09-18].

STEFFENS, P., DAVIDSSON, P. \& FITZSIMMONS, J. 2009. Performance configurations overtime: Implications for growth- and profit oriented strategies. Entrepreneurship and Theory in Practice, 33(1): 125-148.

UNGER, J.M., RAUCH, A., FRESE, M. \& ROSENBUSCH, N. 2009. Human capital and entrepreneurial success: A meta-analytical review. Journal of Business Venturing, 26:341-358.

URBAN, B. 2010. EO and TO at the firm level in the Johannesburg area. South African Journal of Human Resource Management, 8(1):1-9.

URBAN, B. 2012. Tracking the venture creation phases in terms of entrepreneurial self-efficacy: Links to competitiveness of South African ventures. South African Journal of Economic Management Sciences, 15(4):352-365

UZKURT, C., KUMAR, R., KIMZAN, H.S. \& SERT, H. 2012. The impact of environmental uncertainty dimensions on organizational innovativeness: An empirical study on SMEs. International Journal of Innovation Management, 16(2):1250015-1 - 1250015-23.

VAN VUUREN, J. \& WÖRGÖTTER, N. 2013. Market driving behaviour in organisations: Antecedents and outcomes. South African Journal of Economic and Management Sciences, 16(2):115-141.

WIKLUND, J. \& SHEPHERD, D. 2003. Research notes and commentaries: Knowledge-based resources, entrepreneurial orientation, and the performance of small and medium-sized businesses. Strategic Management Journal, 24:1307-1314.

YAMAKAWA, Y., PENG, M. W. \& DEEDS, D.L. 2008. What drives new ventures to internationalize from emerging to developed economies? Entrepreneurship Theory and Practice, 32(1):59-82.

YANG, X., JIANG, Y., KANG, R. \& KE, Y. 2009. A comparative analysis of the internationalization of Chinese and Japanese firms. Asia Pacific Journal of Management, (26):141-162.

YIU, D.W., LAU, CM. \& BRUTON, G.D. 2007. International venturing by emerging economy firms: The Effects of firm capabilities, home country networks, and corporate entrepreneurship. Journal of International Business Studies, 38:519-540.

ZAHRA, S.A., CLONINGER, P., YU, J.F. \& CHOI, Y. 2004. Internationalization: Motive and process. Handbook of research on international entrepreneurship, Blackwell Publishers: Oxford, UK:129-136.

ZAHRA, S.A. \& GEORGE, G., 2002. International entrepreneurship: The current status of the field and future research agenda, In: Hitt, M.A., Ireland, R.D., Camp, S.M. \& Sexton, D.L. (eds.) Strategic entrepreneurship: Creating a new mind-set. Blackwell Publishers: Oxford, UK:255-288

ZAHRA, S.A., IRELAND, R.D. \& HITT, M.A. 2000. International expansion by new venture firms: International diversity, mode of market entry, technological learning and performance. Academy of Management Journal, 43:925-950. 